\title{
水注入後における鼻粘膜上皮透過性の経時的変化について
}

東北大学医学部耳鼻咽喉科学教室（主任：高坂知節教授）

\author{
大平裕子, 高 坂 知 節 \\ 東北大学医学部第一病理学教室 \\ 沢 井 高 志
}

\section{PERMEABILITY CHANGE OF GUINEA PIG NASAL EPITHELIUM AFTER EXPOSURE OF HYPOTONIC SOLUTION}

\author{
HIROKO ODAIRA, M.D. and TOMONORI TAKASAKA, M.D. \\ Department of Otolaryngology, Tohoku University School of Medicine, Sendai
}

TAKASHI SAWAI, M.D.

The First Department of Pathology, Tohoku University School of Medicine, Sendai

One $\mathrm{ml}$ of tap water (hypotonic solution) was poured into the nasal cavities of 40 tracheostomized guinea pigs. After the time interval ranging from 0 to 8 hours, $2 \mathrm{ml}$ of hoarseradish peroxidase saline solution (HRP Sigma typeVI : $3 \mathrm{mg}$ per $\mathrm{ml}$ in saline) was poured into the nasal cavity and septal mucosa was removed at five minutes after the HRP exposure. The mucous membranes were fixed with $2.5 \%$ glutalaldehyde in $0.1 \mathrm{M}$ phosphate buffer and were reacted for localization of peroxidase activity by the method of Graham and Karnovsky. After being postfixed with $2 \% \mathrm{OsO}_{4}$ in $0.1 \mathrm{M}$ phosphate buffer, the blocks were dehydrated through graded ethanol. After embedding into epoxy resin, the $1 \mu \mathrm{m}$ thick sections and $80 \mathrm{~nm}$ ultrathin sections were made and observed under a light microscope and an electron microscope (HITACHI H-600) with the accelerating voltage of $50 \mathrm{KV}$.

The following results were obtained.

1) Immediately after hypotonic water exposure, the permeability of nasal epitherium became more accelerated.

2) HRP precipitates were present in the intercellular space and also in the cytoplasm of some goblet and cilliated cells.

3) It was also confirmed that HRP could enter the intercellular space through the tight junction.

4) The nasal mucosa remained permeable at least for 6 hours after the tap water exposure and its permeability gradually returned to normal thereafter.

Based upon the present experiments, it was concluded that hypotonic water exposure of the nasal cavity could change epitherial permeability although morphological changes of the junctional complexes were not obvious.

Key words : 水刺激, 鼻粘膜, 透過性, HRP A $91-2003-32010$ 


$$
\text { I .はじめに }
$$

最近,スイミングスクールに通う児童の増加に伴い, 水泳後の䁷症状の悪化がしばしば問題となっつている。 前回，著者らは水に上って生ずる鼻粘膜上皮の形態的 変化について検討し，報告した”。るの中て，条件变 えて種々の水を 5 分以上持続的にモルモット鼻腔心注 入すると, 粘膜上皮細胞の空胞形成や細胞間隙の離開 等著明な変化が生じ，注水時間を長くするに従い，上 皮の脱落やさらにその後, 粘膜上皮の再生が認められ ることを指摘した。ししも粘膜の変化は, 水道水と, 消毒剂である次亚塩素酸カルシウム（サラシ粉）溶解 液で大差を認めなかった。すなわち，鼻粘膜上皮に浸 透圧が大きな影響を与えることを示した。

今回，著者は少量の水道水をモルモット鼻腔八注入 後, HRP をトレーサーとして使用し, 鼻粘膜の透過性 の変化を調べた。

\section{II 。対象及び方法}

体重 240〜350gのハートレイ系白色モルモット40 匹を使用した、ネムブタール $25 \mathrm{mg} / \mathrm{kg} に て$ 麻醉後気 管切開を行い，次いで左右鼻腔へそれぞれ $1 \mathrm{ml}$ の水道 水を one shotで注入した。

(実験 1)

その後，所定の時間を置いてから，HRP 6mg を生

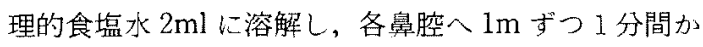
けて注入し，その 5 分後に断頭・鼻中隔粘膜を採取し た. 対照は, 生理的食塩水で溶解したHRPのみを注入 し，5分後に断頭した（図 1).

注水から HRP 注入までの時間は, 図 2 に示すごと <, 直後. 5 分後・ 15 分後・ 45 分後・ 1 時間後・ 2 時 間後・ 3 時間後・ 4 時間後・ 6 時間後・ 8 時間後とし, それぞれモルモットを3匹ずつ使用した。

(実験 2)

HRPの鼻粘膜上皮細胞間隙八の吸収経路を調べる ため, 前述の HRP 液を, 水注入後 2 分間で注入し, そ の直後に断頭し, 同様に重巾隔粘膜を採取した $(\mathrm{N}=$ 2).

採取した鼻中隔粘膜は，害験 $1 ・ 2$ とも $4 \sim 6$ 個に 細断し, $2.5 \%$ グルタールアルデヒドで 2 時間前固定し た，次にペルオキシダーゼ活性を検出するため，Karnovsky 反応を加えてから，1\%オスミニウム酸で2 時間後固定した，次いで系列アルコールで脱水後，エ ポン包埋し、デュポン社製 Sorval Ultra Microtome を用いて, 厚さ $1 \mu$ の光顕用切片を作製し, 無染色のま

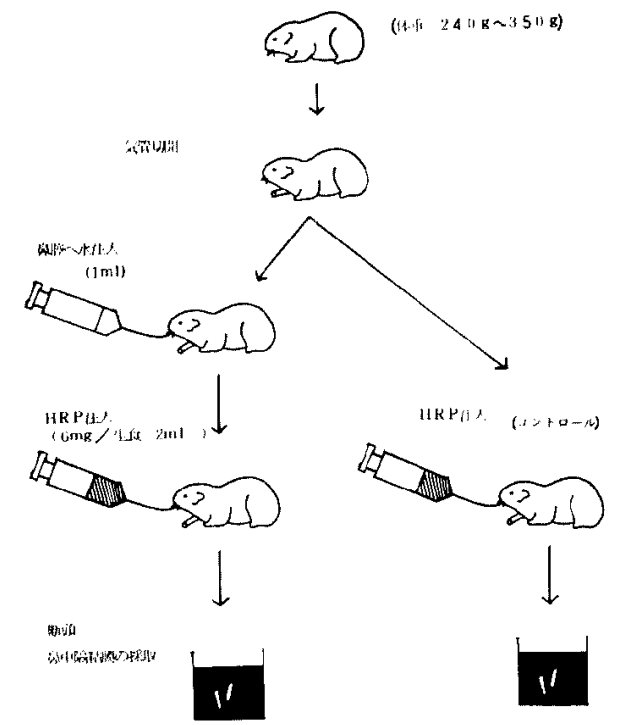

図 1 実験方法

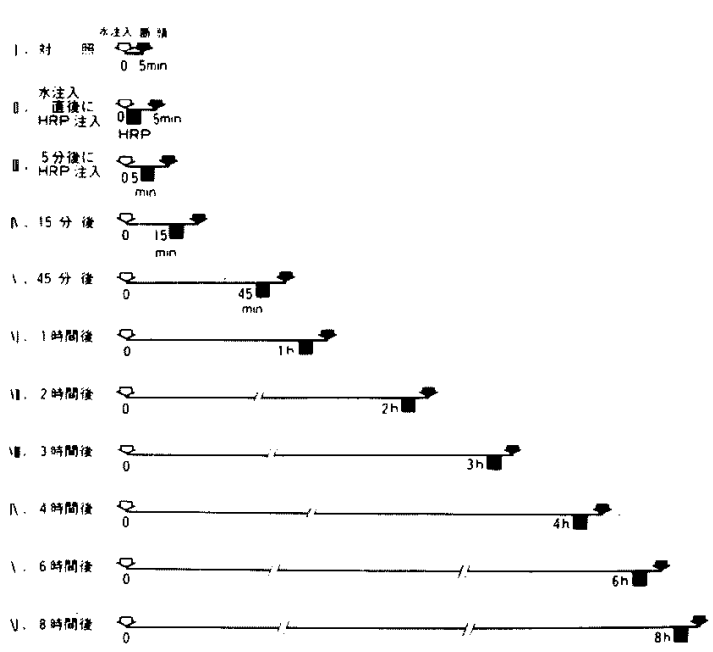

図 2 実験内容

ま，及びトルイジンブルーで染色し，観察した。さら に超薄切片を作製し，日立 $\mathrm{H}-600$ 型電子顕微鏡で観察 した。

\section{（実験 1)}

\section{III、結果}

対照例では, 上皮細胞間隙には HRPは認められず, まれに上皮細胞内の細胞遊離縁に近く HRP を含むラ イソゾームが存在した（写真 1$)$.

注水直後にHRP を注入し，その5 分後には上皮細 胞間隚にかなり大量の HRP が認められ，一部は基底 


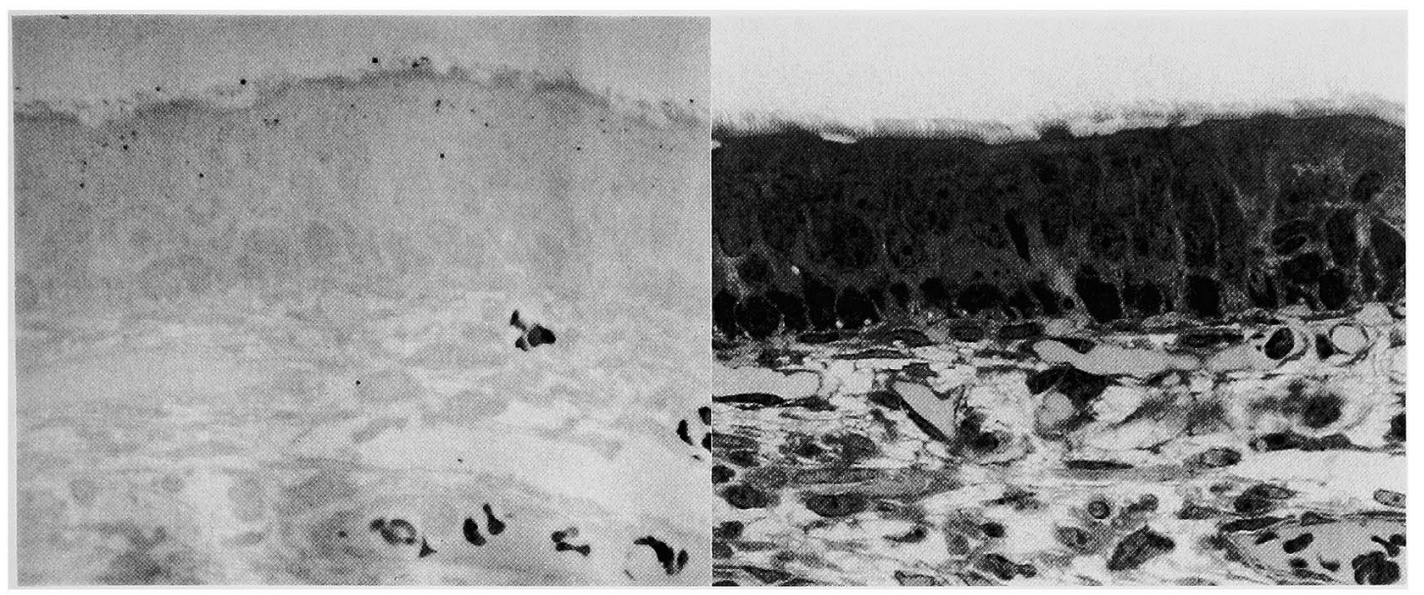

写真 1

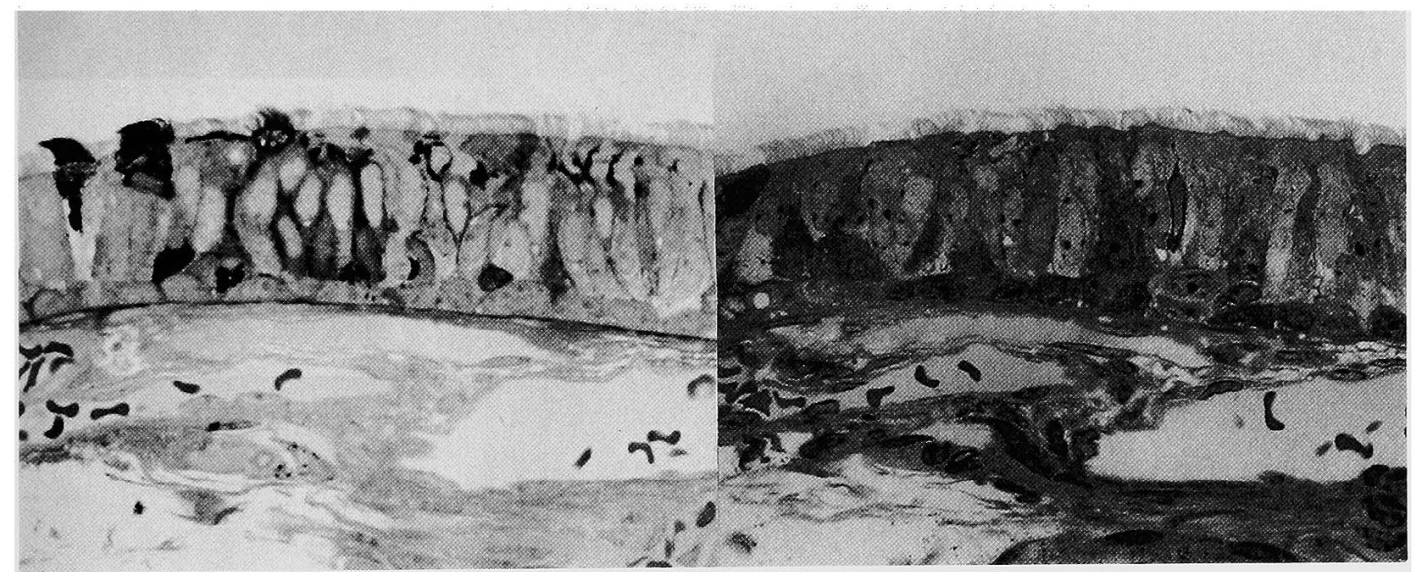

写真 2

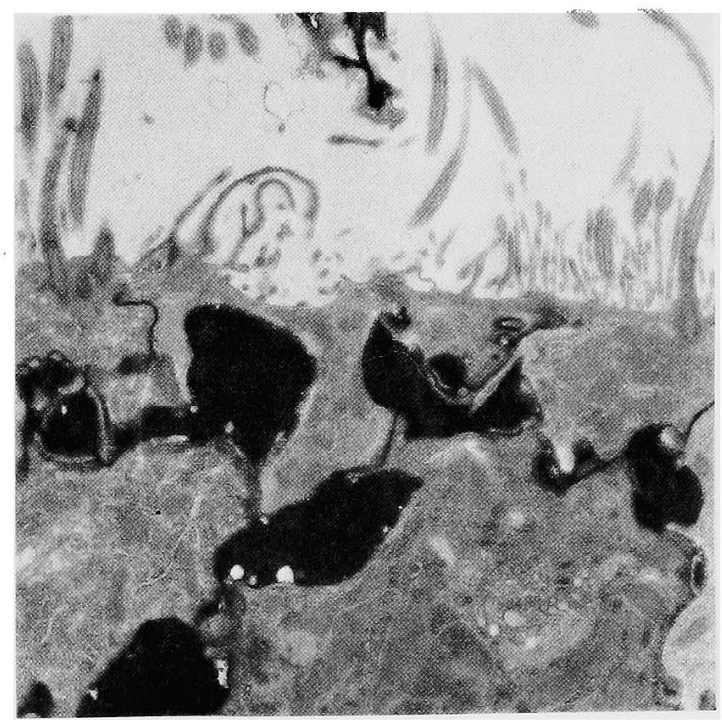

写真 3 


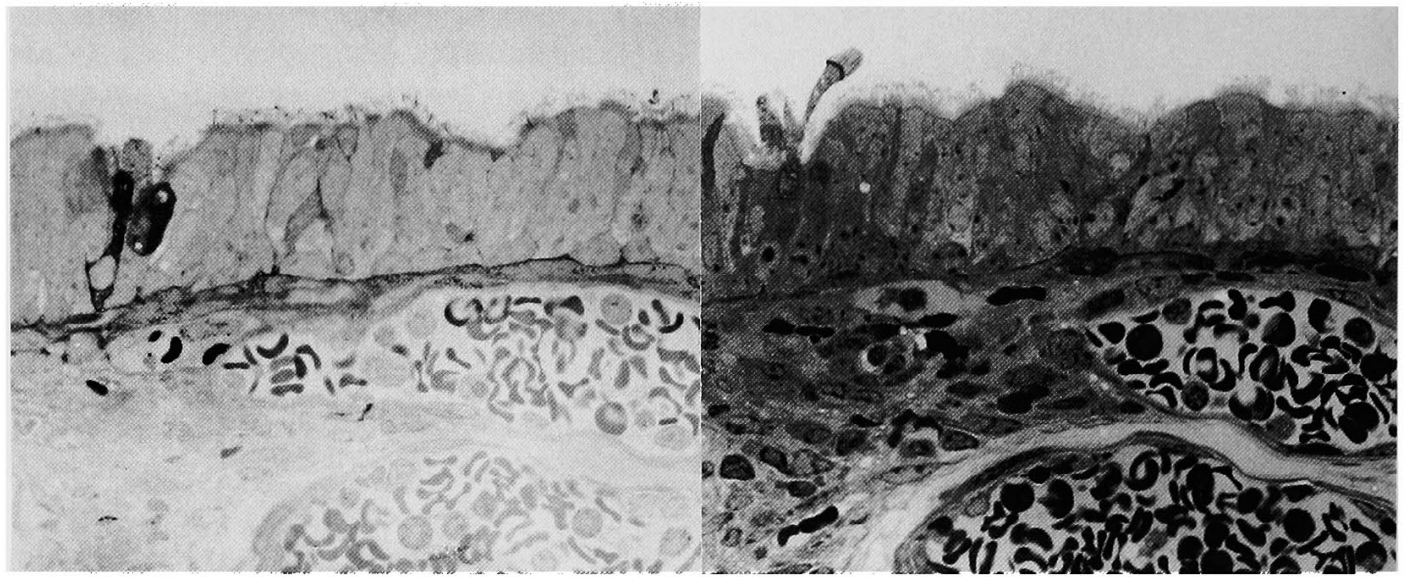

写真 4

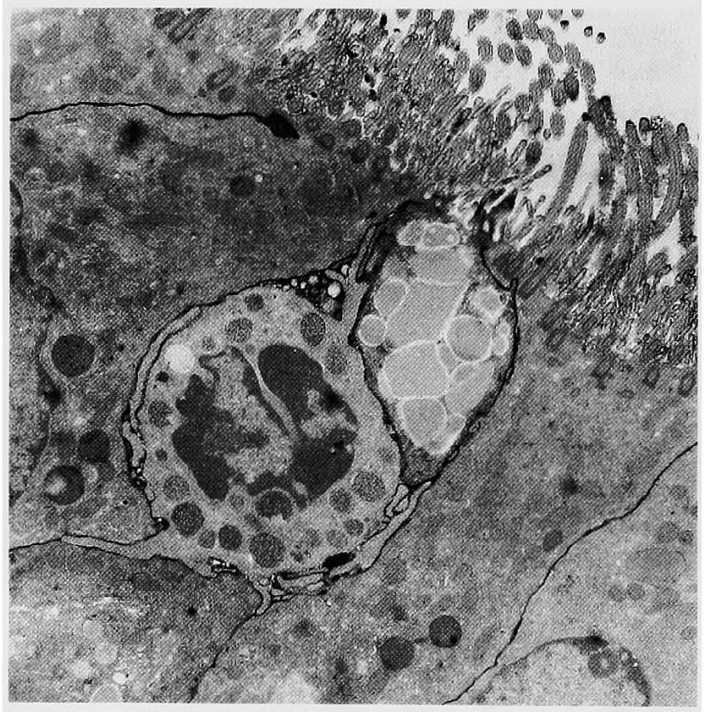

写真

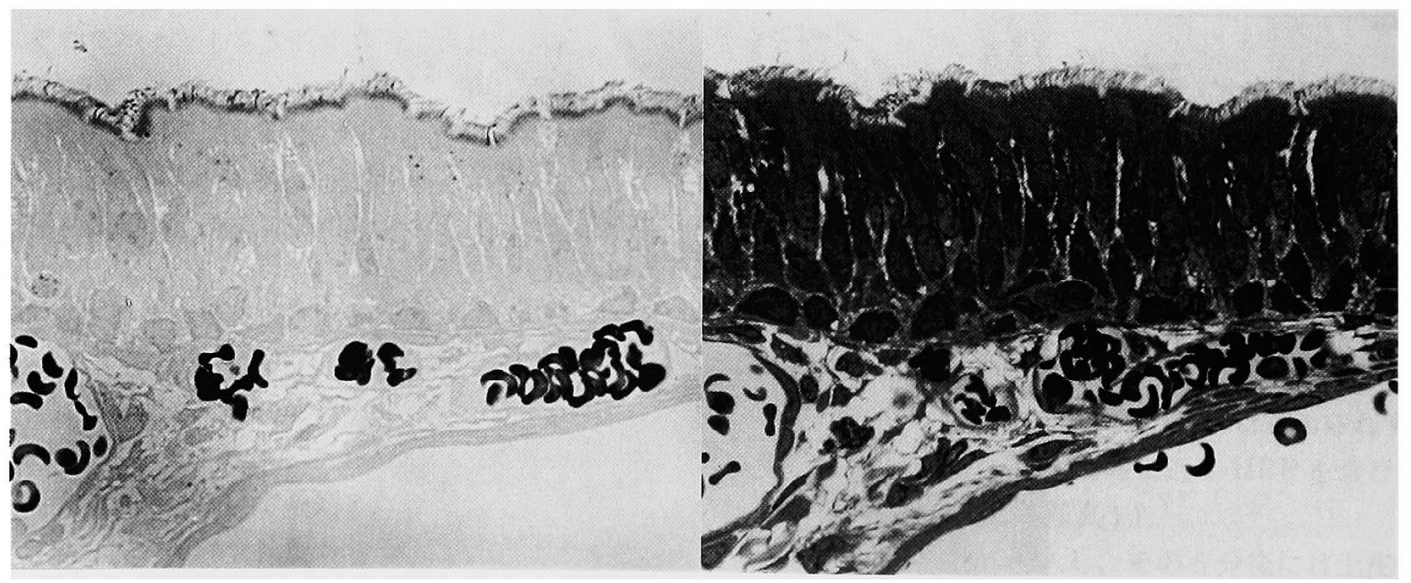




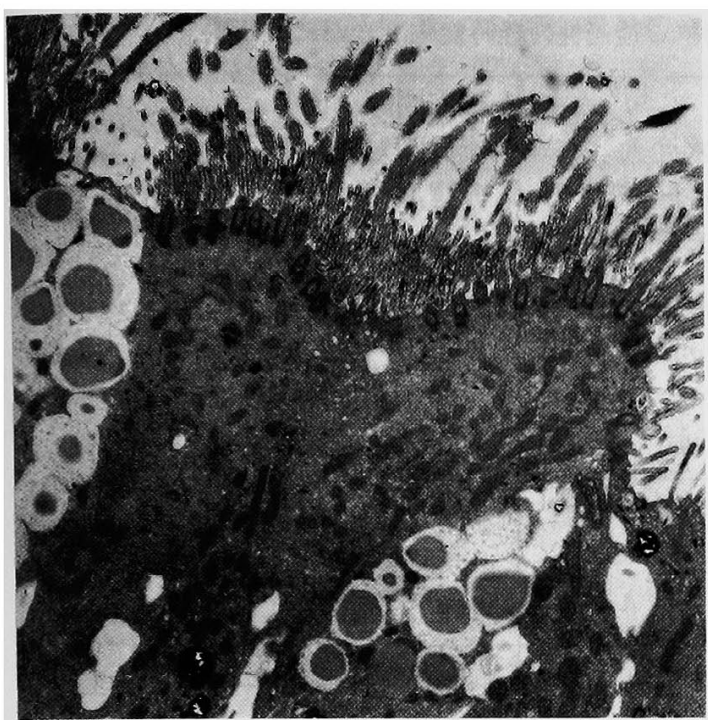

写真 7

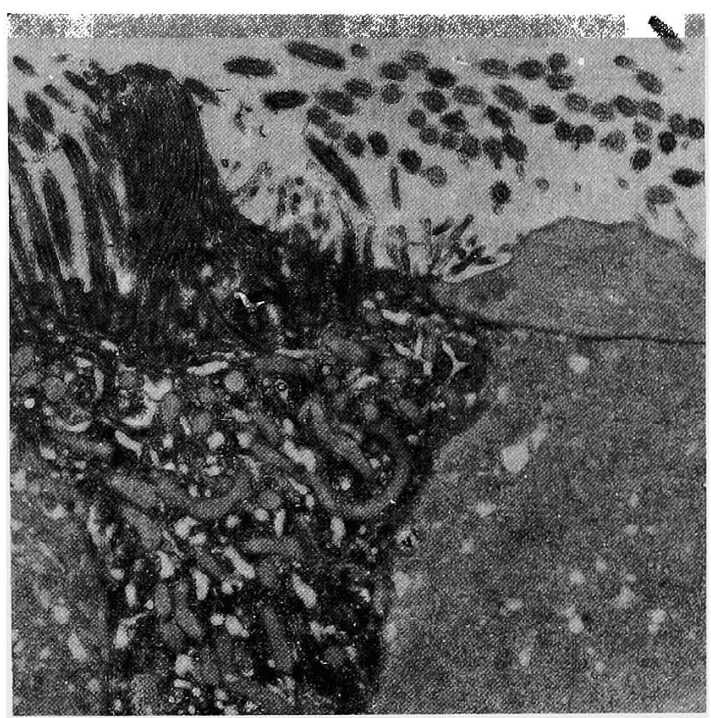

写真 8

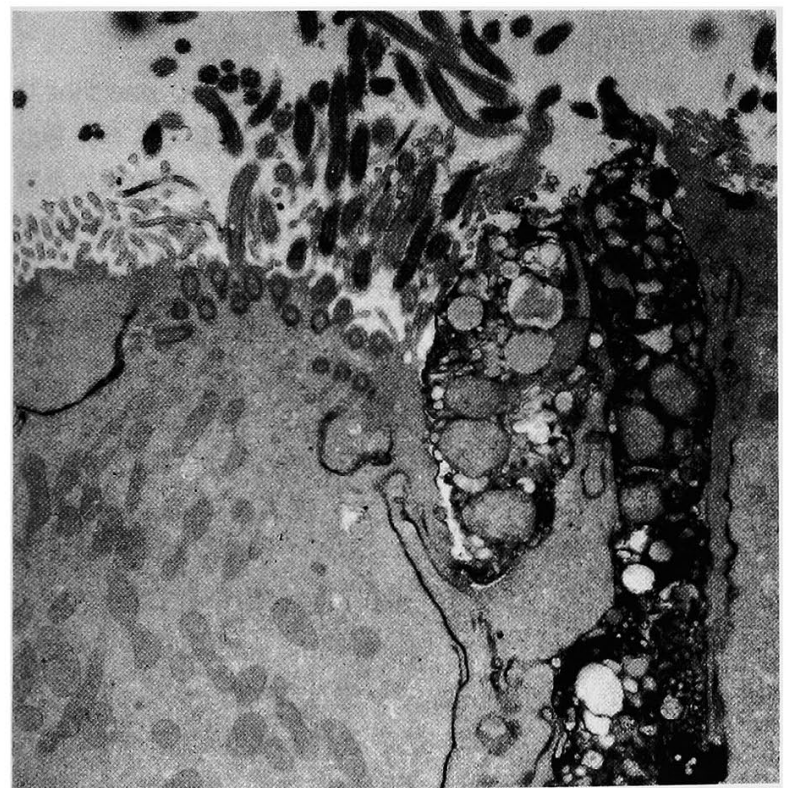

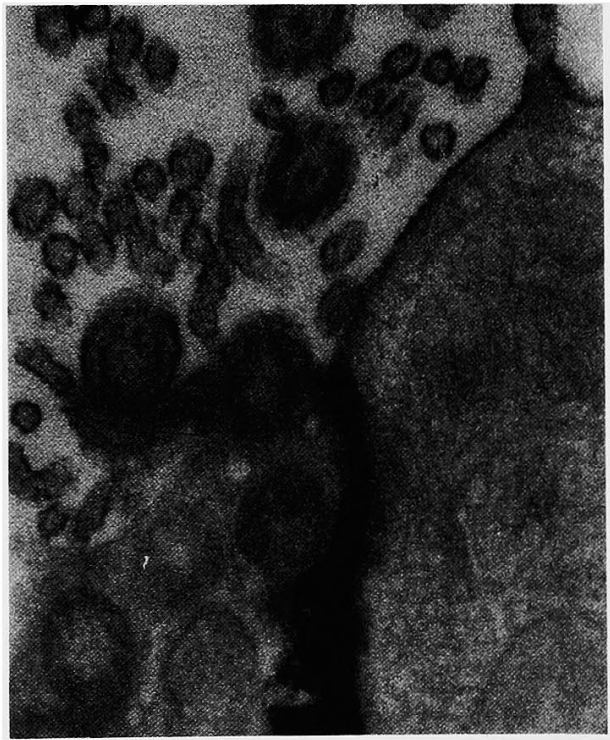

写真 10

写真 9 
表 1 水注入後モルモット鼻粘膜の HRPに対する透過性の経時変化（光顕による観察）

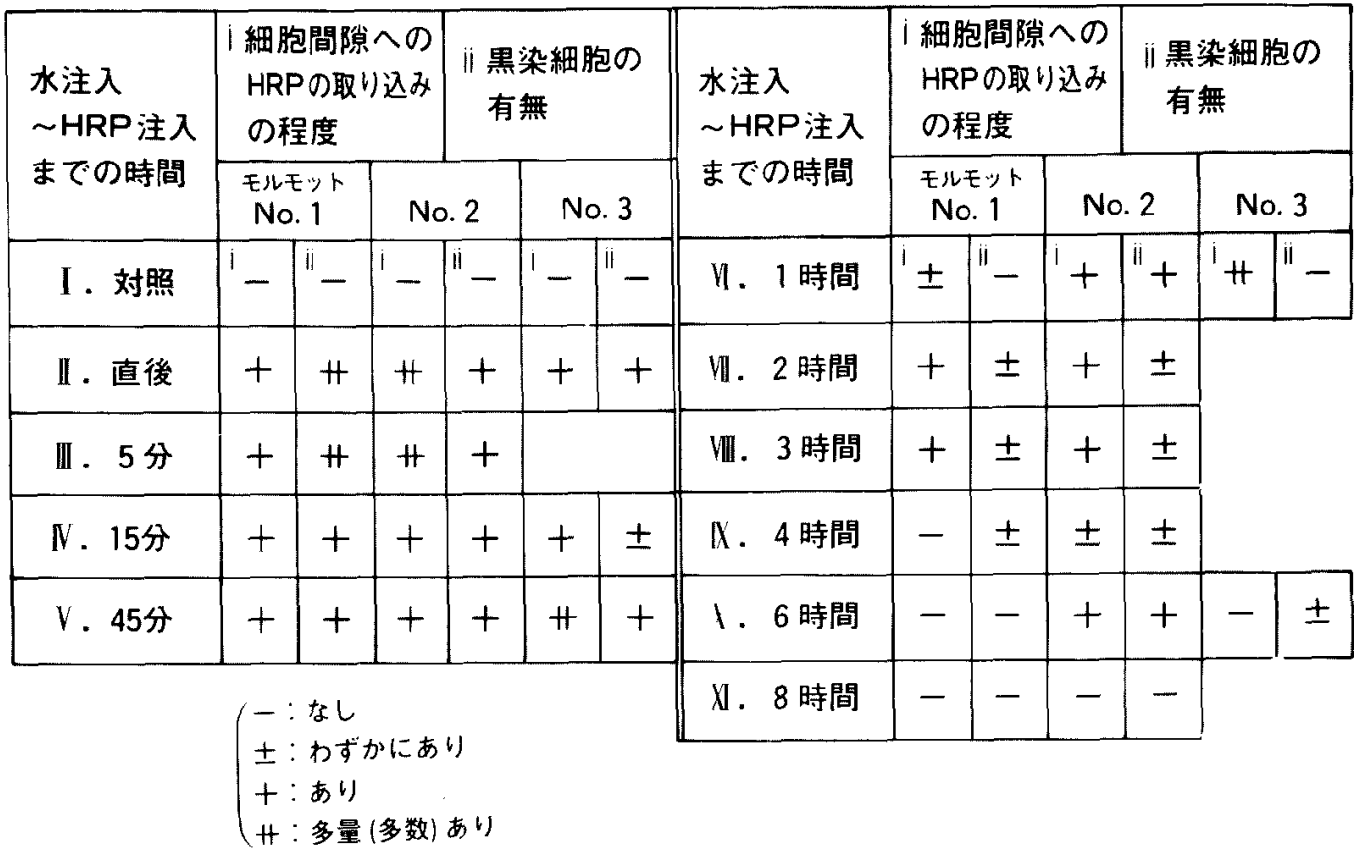

膜にまで及んでいた(写真 2)。電顕で観察すると，上 皮細胞遊離緑に近い細胞間隙の所々に大量の HRPの 存在が認められた（写真 3 ).

注水 15 分後 $\cdot 45$ 分後 1 時間後 $\cdot 2$ 時間後 $\cdot 3$ 時間 後・ 4 時間後にHRP を注入し，その 5 分後に観察する と,やはり HRP が鼻粘膜上皮細胞間吵に認められた が，時間の経過とともに取り込みは徐々に減少する傾 向にあった（写真 $4 \cdot 5)$ ．

注水 6 時間後には細胞間隙への HRP の取り迟みは かなり減少したが，所々 HRP が観察される部位もあ つた.

注水 8 時間後には上皮細胞間隙にHRP は認められ なかった（写真 $6 \cdot 7$ ).

また，微䋐毛及び繊毛も含めて細胞質全体に多量の

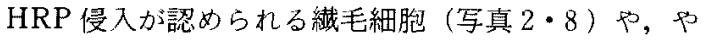
はり細胞質全体が HRP 侵入に上り黒染している杯細 胞（写真 9）が, 注水例で所々認められた。しかし注 水後, 時問の経過とともに黑染細胞は減少し, 注水 8 時閒後には認めら机なかった。

実験 1 の結果を表 1 に示す。

(害験 2)

HRP の鼻粘膜上皮細胞間吵への侵入経路を調べる ため, HRP 液注入直後に断頭すると, HRP が上皮細 胞間の tight junction 通過している様子が観察され
た(写真10).

\section{IV. 考察}

本実験では，モルモット鼻腔へ水道水を one shotで 注入し，鼻粘膜の透過性の経時変化を観察した。その 結果，対照例では HRP はほとんご全く鼻粘膜上皮層 に取り込まれなかったが，水刺激後は，鼻粘膜の透過 性がえ進し，HRP 注容易に上皮細胞間隙及び一部の 上皮細胞の細胞質全体に取り込まれている状態が観察 された。

水注入直後に HRP を注入すると，嶨粘膜上皮細胞 間隙の遊離緑直下の HRP が認められた. HRP の侵入 経路を明らかにするために実験の条件を変えると， HRP が tight junction 通過している様子が観察さ 扎た. 以上より, tight junction は水注入直後には大き く開大するものと思われた. tight junction は徐久に修 複されるものの leaky な状態は数時間持続した。

tight junction は，遊離緑直下で上皮細胞間を結合 し，細胞集団が外界と異なった内部環境を維持する役 割を果たしている21.しかし，タバコの煙31エーテル4 ヒスタミン ${ }^{5)}$ 手術刺激到浸透圧 ${ }^{788)}$ 等が tight junction を変化させ，高分子物質を通過させるようになると報 告されている，本実験においては，水道水と鼻粘膜の 浸透差(水道水： $9 \mathrm{mos} / 1$, 上卜血漿浸透圧：275～290 
mos/1) が tight junctionに作用したものと思われる。 細胞質全体が黒染している細胞に関しては，杯細胞 の分泌顆粒放出後の細胞膜断裂部よりの HRP 侵入, 及び細胞膜の変性に伴う纎毛及び細胞質内への HRP 侵入と思われた。

HRP 透過性亢進の第一の要因として，水による粘 液層の損失が考えられたため，正常鼻粘膜の粘液を染 めてみようと試みたが, 困難であった(末発表デー夕). 今後さらに，粘液層の検討が必要である。

さて, 前回の実験 ${ }^{1)}$ では,プール水がその浸透王によ り鼻粘膜を障害する可能性があることを指摘した。さ らに，本実験から，水道水（プール水と浸透圧はほほ 等しい）の接触により，鼻粘膜の形態的変化が起こる 以前に透過性に変化が生ずることが明らかになり, 抗 原や細菌がより容易に鼻粘膜に侵入する可能性が考え られた。

$$
\text { V. ま と }
$$

水泳時の水が，鼻粘膜上皮の透過性に与える影響を 調バるため，モルモット鼻腔に $1 \mathrm{ml}$ の水道水を注入 し，HRPをトレーサーとして使用して光顕及び電影 で鼻粘膜を観察，以下の結果を得た。

1) 注水直後, 鼻粘膜上皮の HRP 透過性は著明に六 進した。

2) HRPは上皮紐胞間隙及び一部の杯細胞や繊毛 細胞の細胞質全体に認められた。

3）上皮細胞間隚への HRP 侵入は tight junction を 介してなされた。

4) 鼻粘膜上皮の透過性亢進は注水後, 約数時間持続 した。

\section{参考文献}

1) 大平裕子, 小池修二, 高坂知節 他: 種々なる液体, 特 にその浸透圧の鼻粘膜上皮に与える形態学的影響につ いて。 日耳鼻90：1951-1962，1988.

2) Staehelin LA, Hull BE: Junctions Between Living cells.別冊サイエンス．膜と運動：77-86，1980，日本 経済新聞社, 東京.

3) Boucher RC, JohnsonJ, Inoue $\mathrm{S}$ et al : The Effect of Cigarette Smoke on the Permeability of Guinia Pig Airways. LABORATORY INVESTIGATION 43: 94-100, 1980.

4) Richardson I, BouchardT, Ferguson CC: Uptake and Transport of Exogenous Proteins by Respira- tory Epithelium. LABORATORY INVESTIGATION 135: 309-314, 1976.

5) Boucher RC, Ranga V, Pare PD et al: Effect of histamine and methacholine on guinia pig tracheal permeability to HRP : the American Physiological Society 45 : 939-948, 1978.

6) Rhodes PS, Karnovsky MJ: Loss of Macromolecular Barrier Function Associated with Surgical Trauma to the Intestive. LABORATORY INVESTIGATION $25: 220-229,1971$.

7) Wade JB, Karnovsky MJ : Fracture Faces of Os. motically Disrupted Zonulae Occuludentes: The Journal of cell Biology 62 : 344-349, 1974.

8) Humbert F, Grandchamp A Pricam C et al : Mor. phological changes in Tight Junctions of Necturus Maculosus Proximal Tubules Undergoing Saline Diuresis: The Journal of cell Biology 69: 90-96, 1976.

9）遠藤朝彦；慢性疾患・管理における銭練一アレルギー 性嶨炎とスポーツの関わりー. JOHNS 1:773-778, 1985.

（原稿受付 昭和63.3.16日)

別刷請求先 $\mathbf{T} 980$ 仙台市星陵町 1-1

東北大学医学部耳舅咽喉科学教室 大平裕子

\section{付 図説 明}

写真 1.2、4、6は, 左側が無染色, 右側がトル イジンブルー染色.

写真 1 ：対照例。 $(\times 400)$ 上皮層に HRPは認められ ない.

写真 2 : 注水直後にHRP 注入. その5 分後. ( 400)上皮細胞間吵に多量の HRPが認められ る.HRP侵入により黒染した瀻毛細胞も認 められる。

写真 3 : 注水直後にHRP 注入. そO5 分後. ( 6000)細胞間隙に大量の HRPが認められる。

写真 4 : 注水 4 時間後にHRP 注入. その5 分後. （×400）細胞間吵にごくわずか HRPが認め られる。HRP侵入により黒染した杯細胞も 認められる。

写真 5 : 注水 4 時間後にHRP 注入. Z 5 分後. (×4000) 細胞間吵に少量の HRP が認められ 3 .

写真 6 : 注水 8 時間後にHRP 注入. その5分後. 
(×400) 上皮層に HRP は認められない.

写真 7 : 注水 8 時間後に HRP 注入. その 5 分後. $(\times 4500)$ 細胞間吵にHRP は認められない. 細胞内に HRP を含むライソゾームが存在す る。

写真 8 : 注水 5 分後に HRP 注入. その 5 分後。 $(\times$ 6000）微繊毛及び瀻毛も含めて細胞質全体に 多量の HRP が侵入した繊毛細胞が認められ
ろ.

写真 9 : 注水 4 時間後に HRP 注入. その 5 分後. $(\times 5000)$ 細胞質全体に多量の HRP が侵入し た杯細胞が認められる。

写真 10 ：注水 15 分後に HRP 注入. その直後. HRP は上皮細胞の tight junctionを介して細胞間 隙に取り込まれている。 